\title{
Pelatihan Pembuatan Video Interaktif Serta Penggunaan Google Classroom Dalam Pembelajaran Jarak Jauh (PJJ)
}

\author{
Hennie Tuhuteru*1, Moh. Ramli Sukunawatan², Yeris Almendo Iwane 3 \\ 1,2,3Program Studi Informatika, Fakultas Ilmu Komputer, Universitas Kristen Indonesia Maluku \\ *e-mail: hannytuhuteru@gmail.com ${ }^{1}$,liramsukunwatan@gmail.com ${ }^{2}$,yerisiwane98@ gmail.com ${ }^{3}$
}

\begin{abstract}
SMTK Teon Nila Serua is one of the schools which its learning process are affected by the Covid-19 pandemic. This school does not have its own Learning Management System so an alternative is made for students to study in groups in their respective villages and will be visited by the teacher every month. Several problems were found such as unattractive material in the form of a text module, students' difficulty in understanding hardcopy teaching materials, and reprinted teaching materials that should be taken by all students living quite far from the school location. The purpose of this training is to overcome these problems with training on making interactive videos and training on the use of Google Classroom for teachers and students. Activities are carried out in four stages, namely the preparation stage, implementation stage, evaluation, and program sustainability. This activity has been carried out well where there has been an increase in participants' understanding in making interactive videos by 95\% and the use of Google Classroom in simulating the teaching and learning process by $90 \%$.
\end{abstract}

Keywords: Google Classroom, Explee, training, SMTK Teon Nila Serua, Distance Learning.

\begin{abstract}
Abstrak
SMTK Teon Nila Serua merupakan salah satu sekolah yang proses pembelajarannya terkena dampak pandemi Covid-19. Sekolah ini belum memiliki Learning Management System sendiri sehingga dibuat alternatif bagi siswa untuk belajar secara berkelompok di desanya masing-masing dan akan dikunjungi oleh guru setiap bulannya. Permasalahan yang ditemukan seperti materi dibagikan hanya berupa modul teks sehingga berkurangnya minat belajar siswa karena kesulitan dalam memahami bahan ajar tersebut, serta materi ajar yang harus dicetak ulang oleh Guru dan diambil oleh siswa yang tinggal cukup jauh dari lokasi sekolah. Tujuan dari pelatihan ini untuk mengatasi permasalahan tersebut dengan memberikan pelatihan pembuatan video interaktif dan pelatihan Google Classroom untuk guru dan siswa. Kegiatan dilakukan dalam empat tahap, yaitu tahap persiapan, tahap pelaksanaan, evaluasi, dan keberlanjutan program. Kegiatan ini telah terlaksana dengan baik dimana telah terjadi peningkatan pemahaman peserta dalam pembuatan video interaktif sebesar 95\% dan penggunaan Google Classroom dalam simulasi proses belajar mengajar sebesar $90 \%$.
\end{abstract}

Kata kunci: Google Classroom, Pelatihan, SMTK Teon Nila Serua, Pembelajaran Jarak Jauh

\section{PENDAHULUAN}

Penyebaran Covid-19 yang begitu cepat sejak pertama kali diketahui terjadi di Wuhan pada bulan Desember 2019 telah menyebar ke seluruh dunia, termasuk Indonesia (World Health Organization Indonesia, 2020). Penyakit yang telah menjadi pandemi ini menyebar begitu cepat hingga ke Provinsi Maluku dengan satu kasus terkonfirmasi positif pada 23 Maret 2020 (Patty, 2020a). Kondisi ini terjadi merata di seluruh penjuru tanah air dan sangat mengganggu berbagai sektor, baik itu sektor ekonomi, pendidikan dan lain sebagainya (Handayani \& Kurniawan, 2020; Sauban, 2020). Seluruh aktivitas kegiatan masyarakat pun harus dibatasi dengan diberlakukannya Pembatasan Sosial Berskala Besar (PSBB) dimana masyarakat diharuskan untuk bekerja maupun belajar dari rumah untuk mencegah penyebaran penyakit ini yang makin meluas (Mayaut, 2020; MCAMBON, n.d.; Patty, 2020c, 2020b; Salampessy, 2020).

Pada sektor pendidikan, Menteri Pendidikan dan Kebudayaan, Nadiem Anwar Makarim pun mengeluarkan Surat Edaran Menteri Pendidikan dan Kebudayaan Republik Indonesia Nomor 35952/MPK.A/HK/2020 mengenai pembelajaran secara daring dan bekerja dari rumah dalam rangka pencegahan penyebaran Covid-19 (Menteri Pendidikan dan Kebudayaan Republik Indonesia, 2020). Direktorat Jenderal Bimbingan Masyarakat Kristen Kementerian Agama 
Republik Indonesia juga mengeluarkan Surat Edaran Dirjen Bimas Kristen SE B141/DJ.IV/KP.08.2/03/2020 mengenai pembatasan perjalanan dinas, kegiatan, dan aktivitas belajar mengajar serta perkuliahan di lingkungan Dirjen Bimas Kristen untuk mencegah penyebaran Covid-19 (Pentury, 2020). Pendidikan Jarak Jauh (PJJ) juga sebenarnya telah dicanangkan pemerintah melalui Permendikbud RI No. 119 Tahun 2014 tentang penyelenggaraan pendidikan jarak jauh jenjang pendidikan dasar dan menengah. Hal ini menunjukkan bahwa sekolah menengah juga bisa menjalankan PJJ bukan hanya di masa pandemi Covid-19 saja, tetapi juga setelah pandemi ini berlalu. Perlu dikembangkan metode pembelajaran yang menarik minat dan bakat siswa untuk lebih berkarya (Putri, 2018). Penggunaan Learning Management System (LMS) menjadi salah satu teknologi yang telah digunakan oleh berbagai perguruan tinggi dan sekolah di Indonesia untuk PJJ maupun pembelajaran secara mandiri bagi siswa. Salah satu LMS yang paling sering digunakan untuk PJJ berdasarkan hasil survei dari Lembaga Arus Survei Indonesia (ASI) seperti yang diberitakan Kompas.com adalah Google Classroom, yaitu sebesar 26.1 persen (Kamil, 2020; Salsabila, 2020).

Keputusan yang dikeluarkan oleh Pemerintah tersebut juga berdampak pada Sekolah Menengah Teologi Kristen (SMTK) Teon Nila Serua yang harus membatasi proses belajar mengajar di sekolah untuk mencegah penyebaran Covid-19. SMTK Teon Nila Serua berada di Jalan Hj. Adam Malik, Desa Layeni, Kecamatan Teon Nila Serua, Kabupaten Maluku Tengah. Sekolah yang berdiri pada tahun 2006 ini memiliki luas lahan 2000 M2 dengan posisi geografis berada pada titik -3.206356 129.022054 atau 3¹2'22.9"S 12901'19.4"E. Berdasarkan Akreditasi yang dikeluarkan oleh Badan Akreditasi Nasional Sekolah/Menengah (BAN-SM) diketahui SMTK Teon Nila Serua saat ini telah terakreditasi peringkat B dengan predikat Baik berdasarkan Surat Keputusan BAN-SM Nomor 1444/BAN-SM/SK/2019 yang mulai berlaku pada 12 Desember 2019 hingga 12 Desember 2024 (Badan Akreditasi Nasional Sekolah/Menengah, 2020; Tim Dapodikbud, 2020). Berdasarkan profil sekolah SMTK Teon Nila Serua dan dari Data Pokok Pendidikan dan Kebudayaan (Dapodik) diketahui sekolah ini menyelenggarakan kegiatan belajar mengajar pagi selama 6 hari (Tim Dapodikbud, 2020). Tampak depan lokasi SMTK Teon Nila Serua ditunjukkan pada Gambar 1.

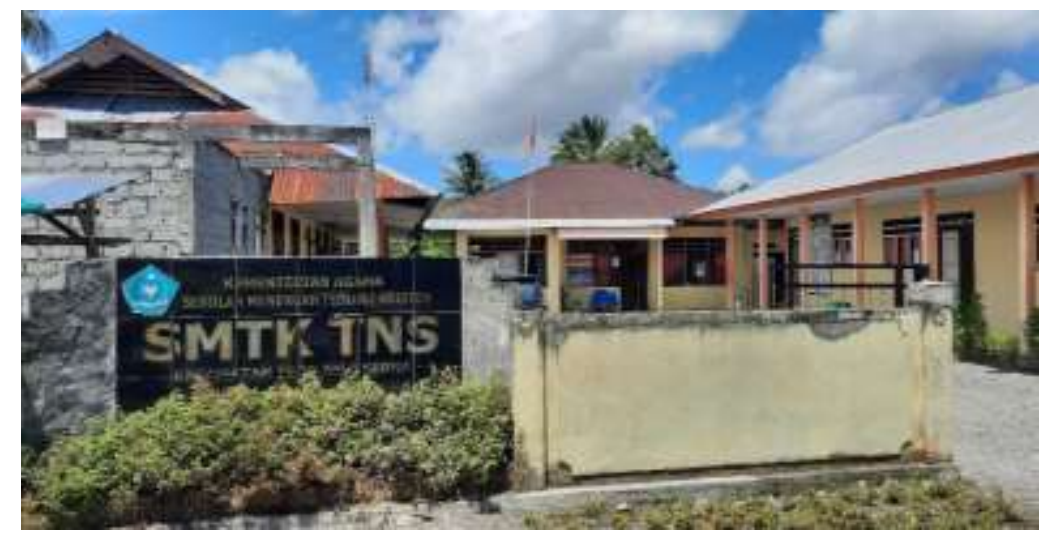

Gambar 1. Tampak Depan SMTK Teon Nila Serua (Sumber: Dok. Pribadi)

Wawancara awal pun dilakukan tim dengan menghubungi via telepon Kepala Sekolah SMTK Teon Nila Serua, Bapak Frans Talarima dan salah satu guru di sekolah tersebut, Ibu Alexandria Hallatu, S.Si pada Selasa, 10 November 2020. Berdasarkan wawancara tersebut diketahui kondisi tempat tinggal siswa SMTK TNS yang tersebar di seluruh Desa di Kecamatan TNS menjadi tantangan tersendiri bagi para guru untuk melaksanakan kegiatan belajar mengajarnya. Berdasarkan data yang diperoleh dari Badan Pusat Statistik, di Kecamatan Teon Nila Serua total terdapat 16 Desa dan 7 Desa diantaranya sulit mengakses lokasi sekolah SMTK TNS (BPS Kabupaten Maluku Tengah, 2020). 
Pihak sekolah pun mengambil kebijakan untuk membentuk kelompok kecil di setiap Desa per tingkatan kelas agar siswa dapat berkumpul dan belajar bersama setiap hari pada jam yang sudah ditentukan. Guru pun membuat bahan ajar kemudian dicetak hardcopy dan diperbanyak kemudian dibagikan ke setiap siswa. Siswa diberikan kesempatan untuk belajar kelompok bersama dengan materi yang sudah diberikan oleh Guru dan mencatat setiap pertanyaan jika mereka belum memahami materi atau mengalami kebingungan tentang topik yang diajarkan. Guru kemudian akan mengunjungi kelompok belajar tersebut setiap satu bulan sekali dikarenakan lokasi Desa dari masing-masing siswa yang cukup jauh bagi mereka untuk menjelaskan atau menjawab pertanyaan dari siswa yang sudah disiapkan sebelumnya.

Kumpulan dokumentasi pada Gambar 2 di bawah menunjukkan bagaimana suasana proses belajar mengajar yang dilakukan oleh Guru SMTK Teon Nila Serua ketika mereka turun ke kelompok belajar siswa untuk membahas materi ataupun menjawab pertanyaan yang sudah disiapkan sebelumnya oleh siswa. Para siswa berkumpul di lokasi tempat belajar kelompok mereka dengan menggunakan pakaian seragam atau pakaian olahraga ketika Guru berkunjung ke lokasi para siswa masing-masing.

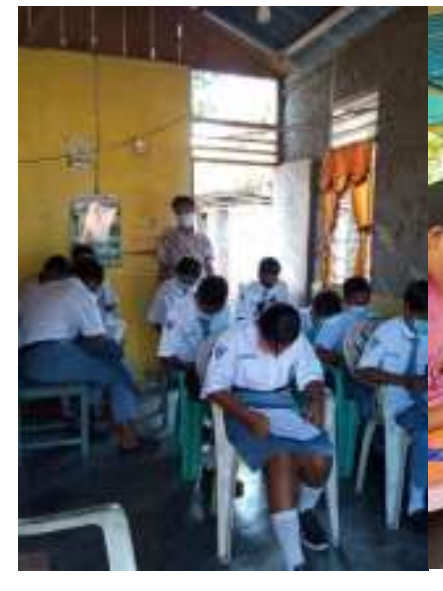

(a)

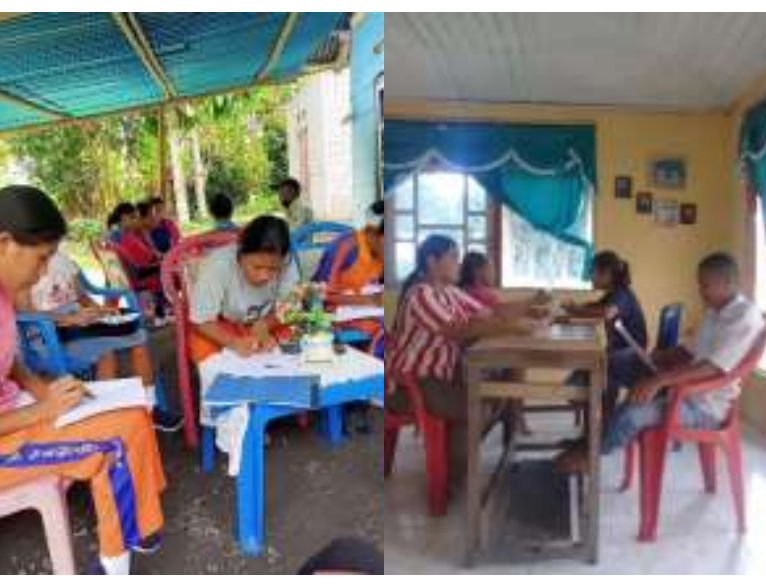

(b) (c)

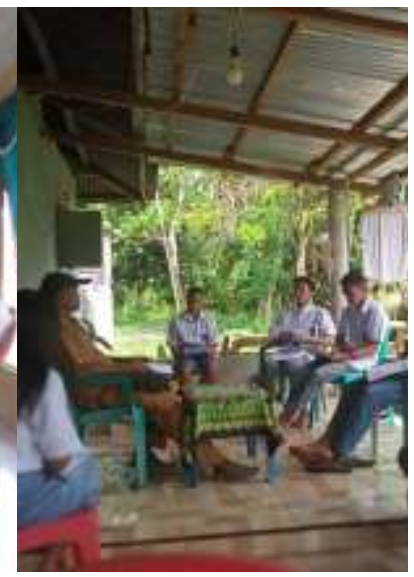

(d)

Gambar 2. Proses Belajar Mengajar (a) (b) Siswa belajar di desanya masing-masing (c) (d) Guru Mengunjungi Kelompok Belajar Siswa tiap Bulan

(Sumber: Dok. SMTK Teon Nila Serua)

Kondisi yang terjadi di sekolah saat ini menunjukkan proses belajar mengajar yang berjalan di SMTK Teon Nila Serua di masa pandemi Covid-19 masih belum optimal karena teknologi yang terkait dengan PJJ juga belum dikuasai atau dimanfaatkan dengan benar. Permasalahan yang menjadi prioritas pada kegiatan Pengabdian kepada Masyarakat (PkM), yaitu (1) Materi yang dipersiapkan hanya berupa modul teks sehingga kurang menarik perhatian siswa; (2) Siswa kesulitan memahami materi yang dibaca melalui bahan ajar hardcopy; dan (3) Bahan ajar yang harus dicetak ulang oleh Guru dan diambil oleh semua siswa yang lokasinya cukup jauh dari lokasi sekolah. Solusi yang dipilih untuk menyelesaikan masalah tersebut, yaitu dengan melakukan kegiatan pelatihan pembuatan video interaktif menggunakan Explee sebagai salah satu media untuk mengolah materi menjadi lebih menarik, serta melakukan pelatihan penggunaan Google Classroom kepada Siswa dan Guru sebagai LMS yang dapat dimanfaatkan untuk berbagi bahan ajar yang bisa diakses kapan dan dimana saja. Wiradharma, dkk (2020) membuktikan bahwa media pembelajaran yang berbasis video menjadikan pembelajaran lebih mudah dan dapat meningkatkan hasil belajar mahasiswa (Wiradharma et al., 2020). Sementara Google Classroom sendiri sangat efektif dalam mengunggah tugas, manajemen kelas, dan komunikasi dengan siswa (Abid Azhar \& Iqbal, 2018). 


\section{METODE}

Metode pelaksanaan kegiatan Pengabdian kepada Masyarakat yang akan dilakukan oleh Tim di SMTK Teon Nila Serua selaku mitra dibagi menjadi 4 Tahapan seperti yang terlihat pada Gambar 3 di bawah ini.

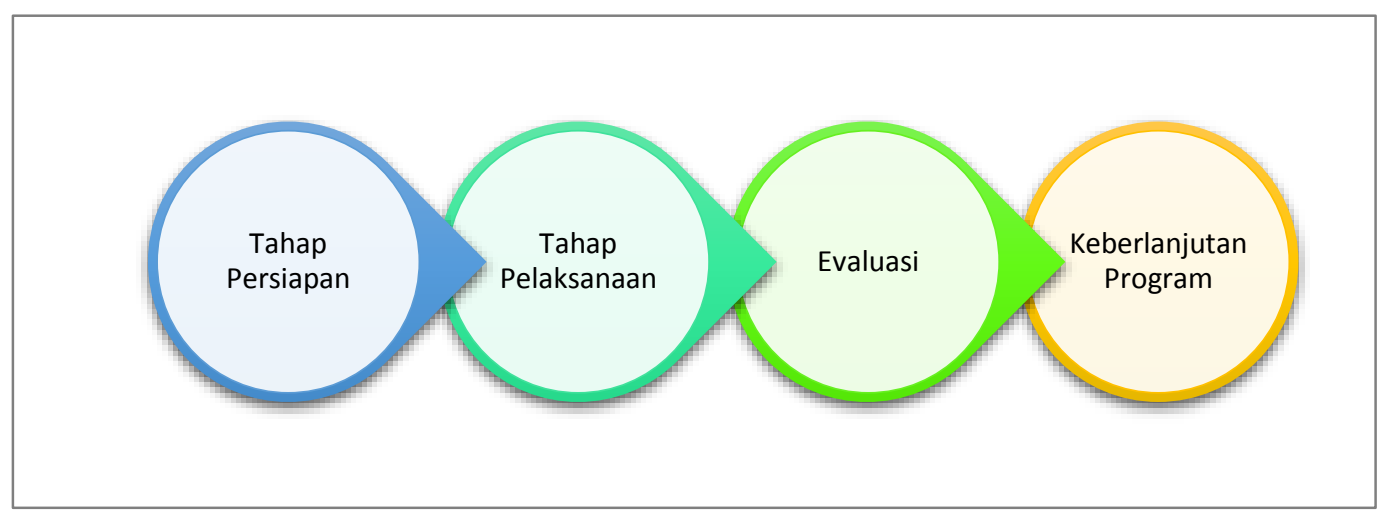

Gambar 3. Tahapan Pelaksanaan Kegiatan

1) Tahap Persiapan

Tahap persiapan meliputi koordinasi dengan mitra, menyepakati waktu pelaksanaan, belanja alat dan bahan yang diperlukan, dan persiapan kuesioner pre-test dan post-test.

2) Tahap Pelaksanaan

Tahap pelaksanaan untuk kegiatan pelatihan penggunaan Google Classroom dilakukan kepada dua peserta yang berbeda, yaitu Siswa dan Guru. Hal ini dikarenakan materi dan aplikasi yang akan dijelaskan memiliki interface yang berbeda untuk pengguna sebagai siswa dan pengguna sebagai guru. Sementara kegiatan kedua untuk pelatihan pembuatan video interaktif dikhususkan hanya untuk guru pengampuh mata pelajaran. Sebelum kegiatan dimulai, Tim sudah membagikan modul e-book yang berisi panduan penggunaan Google Classroom untuk Guru dan Siswa.

\section{a. Pelatihan Pembuatan Video Interaktif}

Pelatihan pembuatan video interaktif menggunakan metode praktik, dan tanya-jawab. Pelatihan ini dikhususkan kepada Guru untuk membuat video pembelajaran sesuai mata pelajaran yang diampuh dengan tahapan kegiatan sebagai berikut:

a) Mitra mempersiapkan ruangan pelatihan, mempersiapkan proyektor LCD bagi Tim dan fasilitas jaringan internet.

b) Slide presentasi pengenalan aplikasi web Explee disiapkan oleh tim.

c) Formulir pre-test dan daftar hadir disebarkan kepada guru untuk mengetahui tingkat pemahaman awal guru terhadap penggunaan aplikasi Explee.

d) Setelah selesai mengisi pre-test dan daftar hadir, peserta diarahkan untuk mempersiapkan Laptop/PC untuk membuka situs web Explee di https://explee.com.

e) Tim memulai kegiatan dengan menjelaskan materi tentang Explee, pengenalan interface aplikasi dan fungsi-fungsinya, serta praktik dan simulasi penggunaan aplikasi tersebut. Sementara tahap ini berlangsung, peserta diperbolehkan langsung bertanya jika ada yang masih kebingungan.

f) Formulir post-test dan daftar hadir disebarkan kepada Guru untuk mengetahui tingkat pemahaman mereka setelah mengikuti kegiatan pelatihan pembuatan video interaktif. 


\section{b. Pelatihan Google Classroom}

Kegiatan pelatihan penggunaan Google Classroom menggunakan metode ceramah, praktik, dan tanya-jawab. Pelatihan ini dilakukan terhadap 2 peserta yang berbeda, yaitu kepada Siswa dan Guru dengan tahapan kegiatan yang sama, sebagai berikut:

a) Mitra mempersiapkan ruangan pelatihan, mempersiapkan proyektor LCD bagi Tim dan fasilitas jaringan internet.

b) Slide presentasi disiapkan oleh tim untuk kegiatan pertama kepada Siswa dan kegiatan kedua kepada Guru.

c) Formulir pre-test dan daftar hadir disebarkan kepada siswa untuk mengetahui tingkat pemahaman awal siswa terhadap penggunaan aplikasi Google Classroom.

d) Formulir yang sama juga akan dibagi pada kegiatan kedua, yaitu pelatihan Google Classroom kepada Guru.

e) Setelah selesai mengisi pre-test dan daftar hadir, peserta diarahkan untuk mempersiapkan gadget mereka, baik itu laptop ataupun smartphone yang dapat digunakan untuk membuka atau menginstal aplikasi Google Classroom.

f) Tim memulai kegiatan dengan menjelaskan materi tentang Google Classroom, pengenalan interface aplikasi dan fungsi-fungsinya, serta praktik dan simulasi penggunaan aplikasi tersebut. Sementara tahap ini berlangsung, peserta diperbolehkan langsung bertanya jika ada yang masih kebingungan.

g) Formulir post-test dan daftar hadir disebarkan kepada Siswa dan Guru untuk mengetahui tingkat pemahaman mereka setelah mengikuti kegiatan pelatihan Google Classroom.

3) Evaluasi

Evaluasi dilakukan sepanjang kegiatan berlangsung, mulai dari persiapan hingga selesainya pelaksanaan kegiatan ini. Berikut adalah beberapa aspek yang digunakan untuk proses evaluasi, antara lain:

a. Pelaksanaan kegiatan sesuai jadwal

b. Koordinasi internal tim dan koordinasi dengan mitra

c. Jumlah kehadiran peserta

d. Kuesioner pre-test dan post-test

e. Situasi selama kegiatan berlangsung

f. Interaksi Tim dengan Peserta

g. Tanggapan Peserta tentang kegiatan dan dampak yang mereka rasakan

4) Keberlanjutan Program

Rencana keberlanjutan program pasca kegiatan PkM ini ditunjukkan pada Tabel 1.

Tabel 1. Keberlanjutan Program

\begin{tabular}{|c|c|c|c|}
\hline \multirow{3}{*}{$\begin{array}{l}\text { No } \\
1 .\end{array}$} & \multicolumn{2}{|c|}{$\begin{array}{c}\text { Rencana } \\
\text { Tindak Lanjut }\end{array}$} & Deskripsi \\
\hline & $\begin{array}{l}\text { Kepala } \\
\text { Sekolal }\end{array}$ & SMTK & $\begin{array}{l}\text { Kepala Sekolah dapat membuat kebijakan untuk penggunaan aplikasi } \\
\text { Google Classroom bagi Siswa dan Guru dalam proses belajar mengajar pada }\end{array}$ \\
\hline & $\begin{array}{l}\text { Teon } \\
\text { Serua }\end{array}$ & Nila & Semester Genap Tahun Ajaran 2020/2021. \\
\hline 2. & $\begin{array}{l}\text { Guru } \\
\text { Teon } \\
\text { Serua }\end{array}$ & $\begin{array}{r}\text { SMTK } \\
\text { Nila }\end{array}$ & $\begin{array}{l}\text { Guru mampu menggunakan aplikasi Google Classroom sebagai tempat } \\
\text { untuk sharing materi, tugas, kuis, memberikan pertanyaan maupun memulai } \\
\text { diskusi dengan para Siswa di kelasnya masing-masing serta mampu } \\
\text { membuat video interaktif menggunakan Explee. }\end{array}$ \\
\hline 3. & $\begin{array}{l}\text { Siswa } \\
\text { Teon } \\
\text { Serua }\end{array}$ & $\begin{array}{r}\text { SMTK } \\
\text { Nila }\end{array}$ & $\begin{array}{l}\text { Siswa juga mampu menggunakan aplikasi Google Classroom untuk melihat } \\
\text { atau mengunduh materi untuk belajar secara mandiri, berdiskusi dengan } \\
\text { Guru, hingga mengirimkan tugas-tugas yang diberikan Guru melalui aplikasi } \\
\text { tersebut dan memahami materi yang diberikan guru melalui video } \\
\text { interaktif. }\end{array}$ \\
\hline
\end{tabular}




\section{HASIL DAN PEMBAHASAN}

\subsection{Pelatihan Pembuatan Video Interaktif}

Kegiatan pelatihan pembuatan video interaktif dilakukan dengan menggunakan aplikasi berbasis web, Explee. Kegiatan ini menggunakan fasilitas yang disediakan oleh SMTK Teon Nila Serua, yaitu ruang Laboratorium Komputer yang di dalamnya sudah tersedia 10-unit komputer dan 3-unit laptop milik pribadi. Pelatihan dilakukan pada Jumat 23 April 2021, selama 4 jam yang dimulai pada pukul 08.30 WIT hingga pukul 12.30 WIT. Suasana pelatihan pembuatan video interaktif dapat dilihat pada Gambar 4.

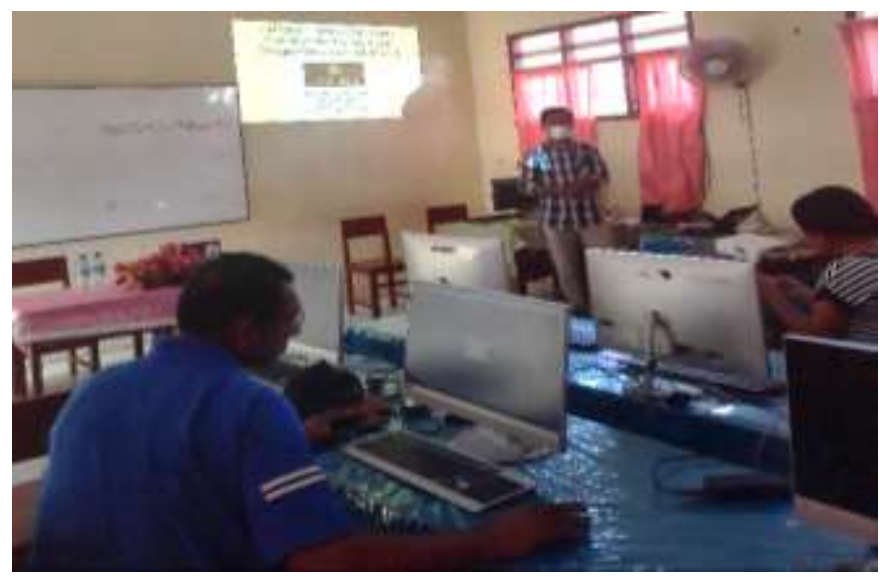

Gambar 4. Suasana Pelatihan Pembuatan Video Interaktif (Sumber: Dok. Pribadi)

Sebelum kegiatan dimulai, dibagikan kuesioner pre-test dan daftar hadir kepada peserta yang ada untuk mengetahui pemahaman awal peseta tentang penggunaan aplikasi berbasis web, Explee. Mitra dipandu untuk membuka aplikasi Explee melalui halaman https://explee.com/, kemudian membuat akun. Pelatihan ini memanfaatkan trial version selama 14 hari yang disediakan oleh Explee. Selanjutnya dijelaskan mengenai fungsi dari fitur-fitur yang ada di halaman dashboard Explee. Setelah itu para peserta diajak untuk mulai membuat video baru secara bersama-sama sesuai arahan dari instruktur. Pada halaman editing video, peserta diajarkan bagaimana menambahkan gambar, audio, menambahkan teks, memanfaatkan fitur text to speech, serta mengatur background dari video yang digunakan. Selanjutnya peserta dipandu untuk mengatur timeline gambar, audio, teks, text to speech, serta menambahkan animasi pada gambar dan teks yang dibuat. Peserta dipandu untuk membuat video pembelajaran dengan durasi 1 menit sesuai dengan materi pelajaran yang dipilih oleh masing-masing peserta.

Setelah selesai membuat video, peserta diarahkan untuk mengekspor video yang telah dibuat dan disiapkan agar bisa diunggah untuk pelatihan Google Classroom selanjutnya. Peserta juga diarahkan untuk bagaimana memperpanjang langganan aplikasi Explee untuk menggunakan fitur Premium yang ada. Kegiatan diakhiri dengan pembagian soal post-test untuk mengetahui tingkat perkembangan peserta mengenai aplikasi Explee. Hasil pre-test menunjukkan rata-rata nilai yang diperoleh peserta $0 \%$ karena sebelumnya peserta belum pernah menggunakan aplikasi tersebut. Peningkatan keterampilan peserta dapat dilihat pada hasil post-test dimana rata-rata pemahaman peserta sebesar 95\%. Tampilan aplikasi Explee yang user-friendly membuat peserta mudah untuk memahami fitur-fitur yang ada dengan lebih cepat.

\subsection{Pelatihan Penggunaan Google Classroom}

Kegiatan selanjutnya dilanjutkan dengan pelatihan penggunaan Google Classroom kepada Guru dan Siswa yang dimulai pukul 10.00 WIT hingga 12.30 WIT dan dilanjutkan pada pukul 13.30 WIT hingga 14.30 WIT. Kegiatan dimulai dengan membuka Google Classroom melalui browser pada alamat https://classroom.google.com/ serta menginstal aplikasi tersebut di 
smartphone masing-masing peserta. Suasana pelatihan penggunaan Google Classroom dapat dilihat pada Gambar 5 di bawah.

Pelatihan dilanjutkan dengan memfokuskan simulasi pada Guru untuk membuat kelas baru di Google Classroom dan mengisi data kelas, seperti nama kelas, tahun ajaran, nama mata kuliah dan ruang. Setelah itu, dijelaskan pengaturan apa saja yang ada pada aplikasi tersebut untuk mengontrol forum, tampilan dan penilaian. Guru kemudian diminta untuk membagikan kode kelas mereka masing-masing kepada siswa yang ada dan Siswa tersebut kemudian join ke kelas Gurunya masing-masing.

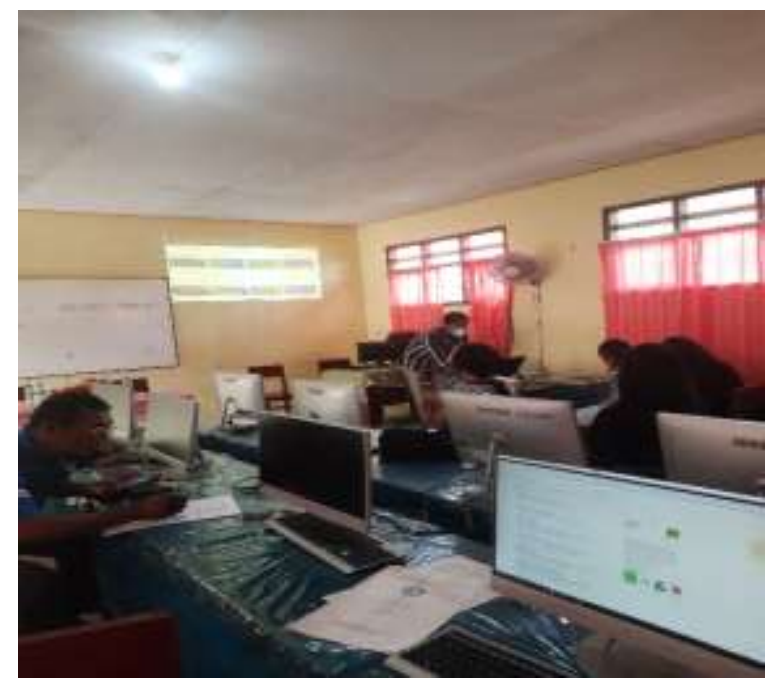

Gambar 5. Suasana Pelatihan Google Classroom di SMTK Teon Nilai Serua (Sumber: Dok. Pribadi)

Kegiatan dilanjutkan dengan simulasi Guru membuat pengumuman dan Siswa kemudian memberikan respond menuliskan komentar pada postingan Guru tersebut. Hal ini dilakukan dengan tujuan agar Guru dapat memberikan pengumuman apapun mengenai kelasnya, baik itu pengumuman jadwal kelas, jadwal ujian tengah semester dan lainnya. Setelah itu, dilakukan simulasi untuk Guru memposting materi untuk mata pelajaran yang diampuhnya, membagikan daftar hadir baik melalui fitur Pertanyaan di Google Classroom dan menggunakan Google Form, serta memberikan tugas kepada Siswa. Pada tahapan pemberian tugas, Siswa diminta untuk membuka tugas yang diberikan Guru dan mengunggah tugasnya yang berupa file dummy dan menambahkan Komentar Pribadi serta Komentar Kelas. Hal ini penting dilakukan agar Guru dan Siswa dapat membedakan mana komentar pribadi yang hanya dapat dibaca oleh Guru dan Siswa bersangkutan, serta mana komentar kelas yang dapat dibaca oleh Guru dan Siswa lain di dalam kelas tersebut.

Pada tahapan terakhir dalam simulasi ini, Guru diminta untuk membuka file tugas yang dikirimkan siswa tersebut dan memberikan penilaian akhir. Guru juga diberikan penjelasan mengenai fitur anggota pada Google Classroom untuk menambahkan Siswa ataupun menambahkan Guru lain baik berupa Team Teaching ataupun pengawas yang mengawasi jalannya proses belajar mengajar secara daring, serta penjelasan mengenai fitur Nilai untuk melihat secara keseluruhan nilai siswa berdasarkan setiap tugas yang diberikan Guru melalui Google Classroom.

Sama seperti pelatihan sebelumnya, pada pelatihan ini juga diberikan pre-test dan posttest melalui Google Form kepada peserta untuk mengetahui tingkat pemahaman dan keterampilan mereka dalam mengoperasikan aplikasi Google Classroom. Rata-rata hasil pre-test untuk penggunaan aplikasi tersebut sebesar 25\%. Hal ini dapat dimaklumi karena peserta baru pertama kali menggunakan LMS ini. Peningkatan terjadi pada rata-rata hasil post-test, yaitu sebesar $90 \%$. Hal ini mengindikasikan bahwa ada peningkatan pemahaman yang signifikan 
terhadap pengetahuan peserta dalam penggunaan aplikasi Google Classroom, serta kegiatan yang dilakukan telah berhasil mencapai target capaian.

Kegiatan diakhiri dengan foto bersama Kepala Sekolah SMTK Teon Nila Serua dan beberapa Guru seperti yang terlihat pada Gambar 6 di bawah ini.

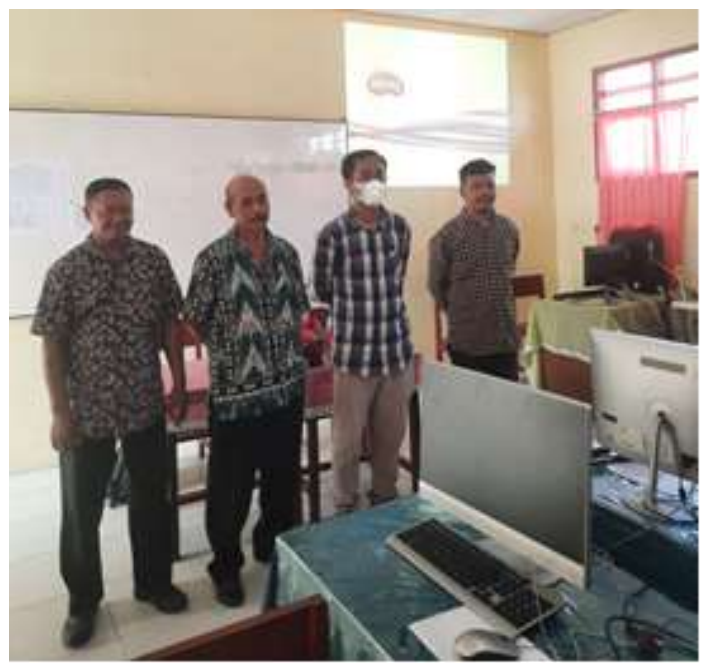

Gambar 6. Foto Bersama Kepala Sekolah SMTK Teon Nila Serua dan Rekan (Sumber: Dok. Pribadi)

\section{KESIMPULAN}

Kegiatan Pengabdian kepada Masyarakat yang dilakukan saat ini didasarkan pada permasalahan faktual dan aktual yang saat ini dialami oleh SMK Negeri 2 Ambon, yaitu (1) Materi yang dipersiapkan hanya berupa modul teks sehingga kurang menarik perhatian siswa; (2) Siswa kesulitan memahami materi yang dibaca melalui bahan ajar hardcopy; serta (3) Bahan ajar yang harus dicetak ulang oleh Guru dan diambil oleh semua siswa yang lokasinya cukup jauh dari lokasi sekolah. Berdasarkan permasalahan tersebut, maka solusi yang ditawarkan, yaitu dengan melakukan kegiatan pelatihan pembuatan video interaktif menggunakan Explee sebagai salah satu media untuk mengolah materi menjadi lebih menarik serta Pelatihan penggunaan Google Classroom kepada Siswa dan Guru sebagai LMS yang dapat dimanfaatkan untuk sharing materi yang diakses kapan dan dimana saja kepada siswa sehingga Guru tidak perlu lagi mencetak ulang bahan ajar dan dibagikan secara manual kepada siswa.

Kegiatan pelatihan tersebut dilakukan dengan metode ceramah, tanya jawab dan praktik simulasi secara langsung. Pelatihan ini juga telah berhasil dilakukan dan mencapai target luaran yang diharapkan, yaitu untuk kegiatan pelatihan pembuatan video interaktif menggunakan aplikasi berbasis web Explee sebesar 95\%, serta peningkatan pemahaman peserta dalam menggunakan LMS Google Classroom sebesar 90\%.

Adanya kegiatan pelatihan pembuatan video interaktif serta penggunaan Google Classroom saat ini diharapkan dapat meningkatkan keterampilan dan pemahaman serta membantu SMTK Teon Nilai Serua dalam mengoptimalkan Pembelajaran Jarak Jauh yang masih terus dilakukan karena pandemi Covid-19 ini.

\section{UCAPAN TERIMA KASIH}

Penulis mengucapkan terima kasih kepada Lembaga Penelitian, Universitas Kristen Indonesia Maluku selaku pihak yang mendanai kegiatan Pengabdian kepada Masyarakat ini dari awal hingga dapat terselesaikan dengan baik. 


\section{DAFTAR PUSTAKA}

Abid Azhar, K., \& Iqbal, N. (2018). Effectiveness of Google Classroom: Teachers' Perceptions. Prizren Social Science Journal, 2(2), 52-66.

Badan Akreditasi Nasional Sekolah/Menengah. (2020). Data Akreditasi Sekolah. BAN-SM. https://bansm.kemdikbud.go.id/akreditasi\#pageContent2

BPS Kabupaten Maluku Tengah. (2020). Kecamatan Teon Nila Serua Dalam Angka 2020.

Handayani, M., \& Kurniawan, D. (2020). Dampak COVID-19, Terganggunya Sektor Perekonomian dan Sampai Berapa Lama Indonesia Bisa Bertahan. https://voi.id/berita/3839/dampakcovid-19-terganggunya-sektor-perekonomian-dan-sampai-berapa-lama-indonesia-bisabertahan

Kamil, I. (2020). Survei: Google Classroom Jadi Platform Belajar Paling Sering Digunakan Saat PJJ. Kompas.Com. https://nasional.kompas.com/read/2020/10/16/18264341/survei-googleclassroom-jadi-platform-belajar-paling-sering-digunakan-saat?page=all

Mayaut, P. F. (2020). Wali Kota: PKM masa uji coba penerapan PSBB di Ambon. https://ambon.antaranews.com/berita/81184/wali-kota-pkm-masa-uji-coba-penerapanpsbb-di-ambon

MCAMBON. (n.d.). Kota Ambon Masuki PSBB Transisi Tahap V. Retrieved October 2, 2020, from https://www.ambon.go.id/kota-ambon-masuki-psbb-transisi-tahap-v/

Menteri Pendidikan dan Kebudayaan Republik Indonesia. (2020). Surat Edaran Menteri Pendidikan dan Kebudayaan Republik Indonesia Nomor 35952/MPK.A/HK/2020. In Mendikbud RI. https://www.kemdikbud.go.id

Patty, R. R. (2020a). Kasus Positif Covid-19 Pertama di Ambon, Maluku Tetapkan KLB Corona. https://regional.kompas.com/read/2020/03/23/10150621/kasus-positif-covid-19pertama-di-ambon-maluku-tetapkan-klb-corona

Patty, R. R. (2020b). Pemkab Maluku Tengah Gratiskan Pengurusan Surat Sehat dan Biaya Rapid Test. Kompas. https://regional.kompas.com/read/2020/06/10/19404181/pemkab-malukutengah-gratiskan-pengurusan-surat-sehat-dan-biaya-rapid-test?page=all

Patty, R. R. (2020c). PSBB Ambon Dimulai 22 Juni, Wali Kota: Pelanggar Diberi Sanksi Tegas. https://regional.kompas.com/read/2020/06/17/17342771/psbb-ambon-dimulai-22-juniwali-kota-pelanggar-diberi-sanksi-tegas

Pentury, T. (2020). Surat Edaran Dirjen Bimas Kristen SE B-141/DJ.IV/KP.08.2/03/2020. Dirjen Bimas Kristen Kemenag RI.

Putri, L. D., \& Soehardi, F. (2018). Pemberdayaan Mahasiswa Fakultas Teknik Dengan Program Kreatifitas Mahasiswa (PKM). Dinamisia: Jurnal Pengabdian Kepada Masyarakat, 2(2), 315321.

Salampessy, T. (2020). Memasuki PSBB Transisi III, Ini Langkah-langkah yang Disiapkan Pemkot Ambon. Maluku Terkini. https://www.satumaluku.id/2020/08/23/memasuki-psbb-transisiiii-ini-langkah-langkah-yang-disiapkan-pemkot-ambon/

Salsabila, P. Z. (2020). Corona Bikin Google Classroom Jadi Aplikasi Terpopuler Artikel ini telah tayang di Kompas.com dengan judul "Corona Bikin Google Classroom Jadi Aplikasi Terpopuler. Kompas.Com. https://tekno.kompas.com/read/2020/03/31/10210067/corona-bikingoogle-classroom-jadi-aplikasi-terpopuler

Sauban, A. (2020, April 1). Empat Sektor Ekonomi yang Paling Tertekan Pandemi Covid-19. https://republika.co.id/berita/q83llp409/empat-sektor-ekonomi-yang-paling-tertekanpandemi-covid19

Tim Dapodikbud. (2020). (60103614) SMTK TEON NILA SERUA WAIPIA. Data Pokok Pendidikan Dan Kebudayaan. http://sekolah.data.kemdikbud.go.id/index.php/chome/profil/2d694a13db2b-4d62-9af6-20c108bd88d0

Wiradharma, G., Arisanty, M., Saputra, A. H., \& Anam, K. (2020). Video Panduan Pembelajaran Online untuk Mahasiswa Tingkat Awal. DINAMISIA: Jurnal Pengabdian Kepada Masyarakat, 4(3), 391-397.

World Health Organization Indonesia. (2020). Media Statement on confirmed COVID-19 cases. https://www.who.int/indonesia/news/detail/02-03-2020-media-statement-on-covid-19 